\title{
ANALISIS PENGARUH MOTIVASI KERJA LINGKUNGAN KERJA DAN KEPEMIMPINAN TERHADAP KINERJA KARYAWAN DI CV MARTHANI
}

\author{
Adhita Maharani Dewi, S.E.,M.M \\ Universitas Kristen Surakarta \\ (ditafreedom@gmail.com) \\ Indah Handaruwati , S.E.,M.M \\ Universitas Kristen Surakarta
}

Penelitian ini tentang pengaruh motivasi kerja lingkungan kerja dan kepemimpinan terhadap kinerja karyawan Di CV Marthani, dengan tujuan untuk menganalisi pengaruh motivasi kerja, lingkungan kerja dan kepemimpinan di CV Marthani. Sehubungan dengan masalah tersebut, diajukan hipotesis sebagai berikut, $\mathrm{H} 1$ : diduga motivasi kerja berpengaruh terhadap kinerja karyawan, $\mathrm{H} 2$ : diduga lingkungan kerja berpengaruh terhadap kinerja karyawan, H3: diduga kepemimpinan berpengaruh terhadap kinerja karyawan. $\mathbf{Y}=\mathbf{a}+\mathbf{b} 1 \mathbf{X} \mathbf{1}+\mathbf{b 2 X 2}+$ b3X3.

Pengambilan sampel menggunakan teknik sensus yaitu pengambilan sampel dengan jumlah populasi yang ada dengan jumlah 35 orang karyawan sebagai sampel. Pengumpulan data menggunakan kuesioner. Data dianalisis menggunakan uji hipotesis dengan menggunakan SPSS.

Hasil dari analisis uji hipotesis penelitian ini menunjukkan bahwa, nilai dari hubungan variabel motivasi kerja, lingkungan kerja, dan kepemimpinan terhadap kinerja karyawan diperoleh nilai $\mathrm{F}_{\text {hitung }}$ sebesar 21,567.

Dari hasil tersebut, dapat disimpulkan bahwa semua variabel independen berpengaruh terhadap kinerja karyawan secara langsung dan variabel yang paling berpengaruh terhadap kinerja karyawan adalah variabel motivasi kerja dan lingkungan kerja.

Kata Kunci: Motivasi, Lingkungan kerja, Kepemimpinan, dan Kinerja Karyawan 


\section{ANALYSIS OF EFFECT OF MOTIVATION WORK ENVIRONMENT WORK AND LEADERSHIP ON THE PERFORMANCE OF EMPLOYEES IN CV MARTHANI}

This study on the effect of work motivation work environment and leadership to employees performance at CV Marthani, with the aim to analyze the effects of work motivation, work environment and leadership in CV Marthani. In connection with the issue, proposed the following hypothesis, H1: allegedly working motivation influence on employee performance, $\mathrm{H} 2$ : allegedly the work environment affect the performance of employees, H3: leadership thought to affect the performance of the employee. $\mathrm{Y}=\mathrm{a}+\mathrm{b} 1 \mathrm{x} 1+\mathrm{b} 2 \mathrm{X} 2+\mathrm{b} 3 \mathrm{X} 3$.

Sampling using census is sampling the number of existing population by the number of 35 employees as a sample. Gathering data using questionnaires. Data were analyzed using hypothesis test using SPSS.

Results of the study hypothesis test analysis shows that, the value of the relationship of work motivation, work environment, and leadership to employee performance values obtained Fhitung 21.567.

From these results, it can be concluded that all the independent variables affect the performance of employees directly and most influential variables on the performance of employees is the variable motivation and work environment.

Keywords : motivation, work environment, Leadership, and Employee Performance. 


\section{Latar Belakang Masalah}

Setiap organisasi dituntut untuk dapat mengoptimalkan sumber daya manusia dan mengelola sumber daya manusia. Pengelolaan sumber daya manusia tidak lepas dari faktor karyawan yang diharapkan dapat berprestasi sebaik mungkin demi mencapai tujuan organisasi. Karyawan merupakan aset utama organisasi dan mempunyai peran yang strategis di dalam organisasi yaitu sebagai pemikir, perencana, dan pengendali aktivitas organisasi. Melihat pentingnya karyawan dalam organisasi, maka karyawan diperlukan perhatian lebih serius terhadap tugas yang dikerjakan sehingga tujuan organisasi tercapai.

Beberapa penelitian tentang pengaruh gaya kepemimpinan, dan motivasi kerja terhadap kinerja pegawai pernah dilakukan, dengan menunjukkan hasil yang berbeda-beda. Seperti penelitian yang dilakukan Suranta (2002); Cahyono dan Suharto (2005); Hidayat (2006); Masrukhin dan Waridin (2006); Kusmawati (2008); Baihaqi (2010); menunjukkan hasil bahwa gaya kepemimpinan dan motivasi kerja berpengaruh positif dan signifikan terhadap kinerja pegawai. Kemudian terdapat pula penelitian dengan hasil yang menunjukkan bahwa gaya kepemimpinan dan motivasi kerja berpengaruh negatif dan tidak signifikan terhadap kinerja pegawai seperti penelitian yang dilakukan oleh Guritno dan Waridin (2005); Dalam perkembangannya, gaya kepemimpinan dan motivasi kerja tidak hanya diperhatikan oleh organisasi swasta, melainkan organisasi pemerintah juga dalam meningkatkan kinerja pegawai. Sumber daya manusia berperan dalam mengolah dan memanfaatkan sumber daya dan material sehingga menjadi produk. Oleh karena itu untuk meningkatkan kinerja, perlu diperhatikan agar sumber daya manusia dapat bekerja secara efisien dan menampilkan kinerja yang bisa memberi sumbangan terhadap produktivitas merupakan masalah mendasar dari berbagai konsep manajemen dan kepemimpinan.

\section{Landasan Teori}

\section{Motivasi Kerja}

Motivasi berasal dari kata latin movere yang berarti dorongan, keinginan, sebab, atau alasan seseorang melakukan sesuatu. Menurut Manullang dalam manajemen personalia (1982;150), motivasi adalah pemberian kegairahan bekerja kepada 
karyawan. Pendekatan untuk memahami motivasi berbeda-beda, karena teori yang berbeda mengembangkan pandangan dan model mereka sendiri. Teori motivasi manusia yang dikembangkan oleh Maslow dalam Mathis 2006, mengelompokkan kebutuhan manusia menjadi lima kategori yang naik dalam urutan tertentu. Sebelum kebutuhan lebih mendasar terpenuhi, seseorang tidak akan berusaha untuk memenuhi kebutuhan yang lebih tinggi. Hirarki Maslow yang terkenal terdiri atas kebutuhan fisiologis, kebutuhan akan keselamatan dan keamanan, kebutuhan akan kebersamaan dan kasih sayang, kebutuhan akan aktualisasi diri. Karyawan akan berusaha untuk menutupi kekurangannya dengan melakukan suatu aktivitas yang lebih baik dalam melaksanakan pekerjaannya. Keinginan yang timbul dalam diri karyawan dapat berasal dari dalam dirinya sendiri maupun berasal dari luar dirinya, baik yang berasal dari lingkungan kerjanya maupun dari luar lingkungan kerjanya. Menurut Arep (2003;51) ada sembilan faktor motivasi, yang dari kesembilan tersebut dapat dirangkum dalam enam faktor secara garis besar, yaitu:

a. Faktor kebutuhan manusia

1) Kebutuhan dasar (ekonomis)

Kebutuhan dasar yang dimaksud di sini adalah kebutuhan akan makanan, pakaian dan perumahan yang biasa disebut sebagai kebutuhan primer. Untuk memenuhi kebutuhan dasar ini sesorang akan bekerja keras dengan mengerahkan segala kemampuannya, karena kebutuhan makanan, pakaian, perumahan merupakan kebutuhan yang paling mendasar yang harus dipenuhi.

2) Kebutuhan rasa aman (psikologis)

Yang termasuk dalam kategori kebutuhan psikologis di sini diantaranya adalah kebutuhan akan status, pengakuan, penghargaan, dan lain-lain. Menurut Arep (2003:61) keinginan karyawan untuk mencapai status tertentu atau untuk menjadi seorang "tokoh", bukan saja berarti bahwa karyawan harus mempunyai kesempatan lebih banyak untuk mencapai kemajuan, akan tetapi juga harus bersedia menerima kewajiban - kewajiban lebih banyak.

3) Kebutuhan sosial 
Menurut Robert Carison: satu cara meyakinkan para karyawan betah bekerja adalah dengan meyakinkan bahwa dirinya memiliki banyak mitra di organisasi. Karyawan dalam suatu organisasi memerlukan berinteraksi dengan sesama karyawan dan dengan sesama atasannya serta menumbuhkan pengakuan atas prestasi kerjanya.

\section{b. Faktor Kompensasi}

Menurut Handoko (2001:155), kompensasi adalah segala sesuatu yang diterima para karyawan sebagai balas jasa bekerja. Kompensasi penting bagi karyawan, karena kompensasi mencerminkan nilai karya karyawan itu sendiri, keluarga, dan masyarakat. Dalam hal pemberian gaji beberapa faktor yang harus diperhatikan, diantaranya:

1) Arti gaji bagi karyawan

Bagi seorang karyawan gaji mempunyai arti yang mendalam, yakni sesuatu yang dapat mempengaruhi tingkat kehidupan karyawan yang bersangkutan bersama keluarganya.

2) Dasar pemberian gaji

Ada beberapa dasar dalam pemberian gaji. Satu diantaranya adalah “ hasil kerja " yakni gaji diberikan berdasarkan jumlah atau nilai barang yang dijual atau yang dihasilkan.

c. Faktor Komunikasi

Menurut Arep (2003:81), komunikasi yang lancar adalah komunikasi terbuka dimana informasi mengalir secara bebas dari atas ke bawah atau sebaliknya. Dalam suatu organisasi komunikasi perlu dijalin secara baik antara atasan dengan bawahan atau sesama bawahan, karena dengan komunikasi yang lancar maka arus komunikasi akan berjalan lancar pula serta tidak terjadi adanya kesalah pahaman yang akan mengakibatkan kesimpangsiuran dalam melaksanakan pekerjaan dalam organisasi.

\section{d. Faktor Kepemimpinan}

Menurut Arep (2003:93) kepemimpinan adalah kemampuan seseorang untuk memguasai atau mempengaruhi orang lain atau masyarakat yang berbedabeda menuju pencapaian tertentu. Dalam mencapai tujuan yakni untuk dapat menguasai atau mempengaruhi serta memotivasi orang lain, maka dalam 
penerapan manajemen sumber daya manusia digunakan beberapa gaya kepemimpinan, diantaranya:

1) Democratic leadership, adalah suatu gaya kepemimpinan yang menitik beratkan kepada kemampuan untuk menciptakan moral dan kemampuan untuk menciptakan kepercayaan.

2) Dictatorial atau autocratic leadership, yakni suatu gaya Leadership yang menitik beratkan kepada "kesanggupan untuk memaksakan "keinginannya yang mampu mengumpulkan pengikut-pengikutnya untuk kepentingan pribadinya dan / atau golongannya dengan kesediaan untuk menerima segala resiko apapun.

3) Paternalistic leadership, yakni bentuk antara gaya pertama (democratic) dan kedua (dictatorial) diatas.

4) Free rain leadership, yakni salah satu gaya kepemimpinan yang $100 \%$ menyerahkan sepenuhnya seluruh kebijaksanaan pengoperasiaan manajemen sumber daya manusia kepada bawahannya dengan hanya berpegang kepada ketentuan-ketentuan pokok yang ditetapkan oleh atasan mereka.

e. Faktor pelatihan

Pelatihan merupakan suatu sarana untuk meningkatkan kemampuan karyawan dalam suatu organisasi. Menurut Arep (2003:108), pelatihan merupakan salah satu usaha untuk mengembangkan sumber daya manusia, terutama dalam hal pengetahuan, kemampuan, keahlian, dan sikap. Manfaat pelatihan bagi karyawan adalah:

1) Meningkatkan motivasi.

2) Meningkatkan pengetahuan kemampuan, dan keterampilan dalam melaksanakan tugas sehari - hari.

3) Meningkatkan rasa percaya diri dan menghilangkan rasa rendah diri.

4) Memperlancar pelaksanaan tugas.

5) Menumbuhkan sikap positif terhadap organisasi.

6) Meningkatkan semangat dan gairah kerja.

7) Mempertinggi rasa peduli terhadap organisasi.

8) Meningkatkan rasa saling menghargai antar karyawan. 
9) Memberikan dorongan bagi karyawan untuk menghasilkan yang terbaik.

10) Memberikan dorongan bagi karyawan untuk memberikan pelayanan yang terbaik.

f. Faktor Prestasi

Penilaian prestasi kerja karyawan bagi organisasi merupakan sarana untuk mengembangkan sumber daya manusia. Karena dengan penilaian prestasi ini akan merasa bahwa hasil kerja mereka diakui oleh pihak organisasi dan kemudian menimbulkan harapan untuk memperoleh kompensasi dari organisasi.

\section{Lingkungan kerja}

Lingkungan kerja merupakan salah satu faktor penting dalam menciptakan kinerja karyawan. Suatu kondisi lingkungan kerja dikatakan baik apabila karyawan dapat melaksanakan kegiatan secara optimal, sehat, aman, dan nyaman. Oleh karena itu penentuan dan penciptaan lingkungan kerja yang baik akan sangat menentukan keberhasilan pencapaian tujuan organisasi. Sebaliknya apabila lingkungan kerja yang tidak baik akan dapat menurunkan motivasi serta semangat kerja dan akhirnya dapat menurunkan kinerja karyawan. Kondisi dan suasana lingkungan kerja yang baik akan dapat tercipta dengan adanya penyusunan organisasi secara baik dan benar sebagaimana yang dikatakan oleh Sarwoto (1991) bahwa suasana kerja yang baik dihasilkan terutama dalam organisasi yang tersusun secara baik, sedangkan suasana kerja yang kurang baik banyak ditimbulkan oleh organisasi yang tidak tersusun dengan baik pula. Menurut Sedarmayanti (2001) menyatakan bahwa secara garis besar, jenis lingkungan kerja terbagi menjadi 2 yaitu:

a. Lingkungan Kerja Fisik

Lingkungan kerja fisik adalah semua keadaan berbentuk fisik yang terdapat di sekitar tempat kerja yang dapat mempengaruhi karyawan baik secara langsung maupun secara tidak langsung Sedarmayanti (2001). Menurut Komarudin (2002) Lingkungan kerja fisik adalah keseluruhan atau setiap aspek dari gejala fisik dan sosial - kultural yang mengelilingi atau mempengaruhi individu. Menurut Alex S. Nitisemito (2002) lingkungan kerja fisik adalah segala sesuatu yang ada di sekitar para pekerja yang dapat mempengaruhi dirinya dalam menjalankan tugas - tugas yang dibebankan, misalnya penerangan, suhu udara, ruang gerak, keamanan, 
kebersihan, musik dan lain-lain. Masalah lingkungan kerja dalam suatu organisasi sangat penting, dalam hal ini diperlukan adanya pengaturan maupun penataan faktor s- faktor lingkungan kerja fisik dalam penyelenggaraan aktivitas organisasi. Faktor - faktor lingkungan kerja fisik adalah sebagai berikut:

1) Pewarnaan

Masalah warna dapat berpengaruh terhadap karyawan di dalam melaksanakan pekerjaan, akan tetapi banyak perusahaan yang kurang memperhatikan masalah warna. Pewarnaan pada dinding ruang kerja hendaknya mempergunakan warna yang lembut.

2) Penerangan

Penerangan dalam ruang kerja karyawan memegang peranan yang sangat penting dalam meningkatkan semangat karyawan sehingga mereka akan dapat menunjukkan hasil kerja yang baik, yang berarti bahwa penerangan tempat kerja yang cukup sangat membantu berhasilnya kegiatan-kegiatan operasional organisasi.

3) Udara

Di dalam ruangan kerja karyawan dibutuhkan udara yang cukup, dimana dengan adanya pertukaran udara yang cukup, akan menyebabkan kesegaran fisik dari karyawan tersebut.

4) Suara bising

Suara bising tersebut dapat merusak konsentrasi kerja karyawan sehingga kinerja karyawan bisa menjadi tidak optimal. Oleh karena itu setiap organisasi harus selalu berusaha untuk menghilangkan suara bising tersebut atau paling tidak menekannya untuk memperkecil suara bising tersebut.

5) Ruang Gerak

Suatu organisasi sebaiknya karyawan yang bekerja mendapat tempat yang cukup untuk melaksanakan pekerjaan atau tugas. Dengan demikian ruang gerak untuk tempat karyawan bekerja seharusnya direncanakan terlebih dahulu agar para karyawan tidak terganggu di dalam melaksanakan pekerjaan di samping itu juga perusahaan harus dapat menghindari dari pemborosan dan menekan pengeluaran biaya yang banyak.

6) Keamanan

ISSN: $2337778 X$ 
Di sini yang dimaksud dengan keamanan yaitu keamanan yang dapat dimasukkan ke dalam lingkungan kerja fisik. Jika di tempat kerja tidak aman karyawan tersebut akan menjadi gelisah, tidak bisa berkonsentrasi dengan pekerjaannya serta semangat kerja karyawan tersebut akan mengalami penurunan. Oleh karena itu sebaiknya suatu organisasi terus berusaha untuk menciptakan dan mempertahankan suatu keadaan dan suasana aman tersebut sehingga karyawan merasa senang dan nyaman dalam bekerja.

7) Kebersihan

Lingkungan kerja yang bersih akan menciptakan keadaan disekitarnya menjadi sehat. Oleh karena itu setiap organisasi hendaknya selalu menjaga kebersihan lingkungan kerja.

\section{b. Lingkungan Kerja Non Fisik}

Lingkungan kerja non fisik adalah semua keadaan yang terjadi yang berkaitan dengan hubungan kerja, baik hubungan dengan atasan maupun hubungan dengan bawahan sesama rekan kerja, ataupun hubungan dengan bawahan (Sedamayanti, 2001). Apabila hubungan seorang karyawan dengan karyawan lain dan dengan pimpinan berjalan dengan sangat baik maka akan dapat membuat karyawan merasa lebih nyaman berada di lingkungan kerjanya. Ada 5 aspek lingkungan kerja non fisik yang bisa mempengaruhi perilaku karyawan, yaitu:

1) Struktur kerja, yaitu sejauh mana bahwa pekerjaan yang diberikan kepadanya memiliki struktur kerja dan organisasi yang baik.

2) Tanggung jawab kerja, yaitu sejauh mana pekerja merasakan bahwa pekerjaan mengerti tanggung jawab mereka serta bertanggung jawab atas tindakan mereka.

3) Perhatian dan dukungan pemimpin, yaitu sejauh mana karyawan merasakan bahwa pimpinan sering memberikan pengarahan, keyakinan, perhatian serta menghargai mereka.

4) Kerja sama antar kelompok, yaitu sejauh mana karyawan merasakan ada kerjasama yang baik diantara kelompok kerja yang ada. 
5) Kelancaran komunikasi, yaitu sejauh mana karyawan merasakan adanya komunikasi yang baik, terbuka, dan lancar, baik antara teman sekerja ataupun dengan pimpinan.

Kedua jenis lingkungan kerja di atas harus selalu diperhatikan oleh organisasi. Terkadang organisasi hanya mengutamakan salah satu jenis lingkungan kerja di atas, tetapi akan lebih baik lagi apabila keduanya dilaksanakan secara maksimal. Dengan begitu kinerja karyawan bisa akan lebih maksimal. Peran seorang pemimpin benar-benar diperlukan dalam hal ini. Pemimpin harus bisa menciptakan sebuah lingkungan kerja baik dan mampu meningkatkan kinerja karyawan.

\section{Kepemimpinan}

Kepemimpinan adalah penggunaan pengaruh untuk memotivasi karyawan agar mencapai sasaran organisasi. Menurut pendapat Josep C.Rost dalam Triantoro Safaria, (2004) kepemimpinan adalah sebuah hubungan yang saling mempengaruhi diantara pemimpin dan pengikut yang menginginkan perubahan nyata yang mencerminkan tujuan bersamanya. Dalam upaya melaksanakan kepemimpinan yang efektif, selain memiliki kemampuan dan keterampilan dalam kepemimpinan, seorang pemimpin sebaiknya menentukan gaya kepemimpinan yang tepat sesuai dengan situasi dan kondisi anggota kelompok. Banyak studi ilmiah yang dilakukan oleh banyak ahli mengenai kepemimpinan, dan hasilnya berupa teori-teori tentang kepemimpinan, sehingga teori-teori yang muncul menunjukkan perbedaan.

\section{Kinerja Karyawan}

Kinerja karyawan sering diartikan sebagai pencapaian tugas, dimana karyawan dalam bekerja harus sesuai dengan program kerja organisasi untuk menunjukkan tingkat kinerja organisasi dalam mencapai visi, misi, dan tujuan organisasi. Menurut Gibson (1996) kinerja karyawan adalah hasil yang diinginkan dari pelaku. Kinerja karyawan adalah tingkat terhadapnya para karyawan mencapai persyaratan pekerjaan (Simamora:2004). Menurut Mathis (2006:113) faktor yang mempengaruhi kinerja karyawan yaitu kemampuan karyawan untuk pekerjaan tersebut, tingkat usaha yang dicurahkan, dan dukungan organisasi yang di terimanya. Faktor-faktor yang mempengaruhi karyawan dalam bekerja, yaitu 
kemampuan karyawan untuk melakukan pekerjaan tersebut, tingkat usaha yang dicurahkan, dan dukungan organisasi. Ada tiga alasan yang berkaitan mengapa penentuan sasaran mempengaruhi kinerja yaitu:

a. Penentuan sasaran mempunyai dampak mengarahkan yaitu memfokuskan aktivitas-aktivitas kearah tertentu dari pada kearah lainnya.

b. Disebabkan oleh sasaran-sasaran yang telah diterima, maka orang-orang cenderung mengarahkan upaya secara proporsional terhadap kesulitan sasaran.

c. Sasaran-sasaran yang sukar akan membuahkan ketekunan dibandingkan sasaran-sasaran yang ringan.

Kinerja karyawan pada dasarnya adalah hasil karya karyawan selama periode tertentu dibandingkan dengan berbagai kemungkinan, misalnya standar, target/sasaran atau kriteria yang telah ditentukan terlebih dahulu dan telah disepakati bersama. Menurut Handoko (2000: 135-137), penilaian prestasi kinerja merupakan proses melalui mana organisasi-organisasi mengevaluasi atau menilai prestasi kinerja karyawan. Kegunaan-kegunaan penilaian prestasi kinerja sebagai beriku:

a. Perbaikan prestasi kinerja

Umpan balik pelaksanaan kerja kemungkinan karyawan, manajer, dan departemen personalia dapat memperbaiki kegiatan-kegiatan mereka untuk memperbaiki prestasi.

b. Penyesuaian-penyesuaian kompensasi

Evaluasi prestasi kerja membantu para pengambil keputusan dalam menentukan kenaikan upah, pemberian bonus, dan bentuk kompensasi lainnya.

c. Keputusan-keputusan penempatan

Promosi, transfer, dan demosi biasanya didasarkan pada prestasi kinerja masa lalu atau antisipasinya. Promosi sering merupakan bentuk penghargaan terhadap prestasi kerja masa lalu.

d. Kebutuhan-kebutuhan pelatihan dan pengembangan 
Prestasi kinerja yang tidak baik mungkin menunjukkan kebutuhan latihan. Demikian juga prestasi yang baik mungkin mencerminkan potensi yang harus dikembangkan.

e. Perencanaan dan pengembangan karir

Umpan balik prestasi mengarahkan keputusan-keputusan karir, yaitu tentang jalur karir tertentu yang harus diteliti.

f. Penyimpangan-penyimpangan proses staffing

Prestasi kinerja yang baik atau salahs mencerminkan kekuatan atau kelemahan prosedur staffing departemen personalia.

g. Ketidakakuratan informasional

Prestasi kinerja yang tidak baik mungkin menunjukkan kesalahankesalahan dalam informasi analisis jabatan, rencana-rencana sumber daya manusia, atau komponen-komponen lain sistem manjemen personalia. Menggantungkan diri pada informasi yang tidak akurat dapat menyebabkan keputusan-keputusan personalia yang tidak diambil tepat.

h. Kesalahan-kesalahan desain pekerjaan Prestasi kinerja yang tidak baik merupakan suatu tanda kesalahan dalam desain pekerjaan. Penilaian prestasi membantu diagnosa kesalahankesalahan tersebut.

i. Kesempatan kinerja yang adil

Penilaian prestasi kinerja secara akurat akan menjamin keputusankeputusan penempatan internal diambil tanpa diskriminasi.

j. Tantangan-tantangan eksternal

Kadang-kadang prestasi kinerja dipengaruhi oleh faktor-faktor di luar lingkungan kinerja, seperti keluarga, kesehatan, kondisi finansial, atau masalah-masalah pribadi lainnya.

Menurut Dessler (1992), penilaian kinerja merupakan upaya membandingkan prestasi aktual karyawan dan prestasi kerja yang diharapkan darinya. Dalam penilaian kinerja karyawan tidak hanya menilai secara fisik, tetapi pelaksanaan pekerjaan secara keseluruhan menyangkut berbagai bidang seperti kemampuan kerja, kerajinan, disiplin, hubungan kerja, atau hal-hal khusus sesuai 
dengan bidang dan tingkatan pekerjaan. Faktor-faktor penilaian kinerja adalah sebagai berikut:

a. Kualitas pekerjaan, meliputi akurasi, ketelitian, penampilan, dan penerimaan keluaran.

b. Kuantitas pekerjaan, meliputi volume keluaran dan kontribusi.

c. Supervisi yang diperlukan, meliputi membutuhkan saran, arahan, atau perbaikan.

d. Kehadiran, meliputi ketepatan waktu, disiplin, dapat dipercaya/diandalkan;

e. Konservasi, meliputi pencegahan pemborosan, kerusakan, dan pemeliharaan peralatan.

\section{Hubungan antara Motivasi kerja, Lingkungan Kerja dan kepemimpinan Terhadap Kinerja karyawan}

Motivasi adalah hasrat untuk berupaya guna memberikan manfaat bagi orang lain (Grant, 2008) menunjukkan tingkat di mana perilaku para karyawan berhasil di dalam memberikan kontribusi tujuan-tujuan organisasi (Motowidlo, 2003). Kami menggunakan teori kepercayaan dan teori desain pekerjaan untuk menyatakan bahwa para karyawan akan lebih memiliki keyakinan terhadap komunikasi misi dan tindakan para manajer yang dapat dipercaya. Ini akan memungkinkan karyawan untuk melihat bagaimana pekerjaan mereka membantu pihak yang menerima manfaat serta meningkatkan kinerja karyawan. Selain itu lingkungan kerja juga tidak kalah pentingnya didalam pencapaian kinerja karyawan. Dimana lingkungan kerja mempengaruhi karyawan dalam menyelesaikan pekerjaannya. Dengan adanya lingkungan kerja yang memadai tentunya akan membuat karyawan betah bekerja, sehingga akan timbul semangat kerja dan kegairahan kerja karyawan dalam melakasanakan pekerjaannya, kinerja karyawan akan meningkat.

\section{Penelitian Terdahulu}

Ada beberapa penelitian terdahulu yang berkaitan dengan motivasi kerja, lingkungan kerja, dan kinerja karyawan. Emilia Rosyana Putri (2001) dalam penelitiannya yang berjudul pengaruh faktor-faktor motivasi terhadap kinerja karyawan. Analisis penelitian yang digunakan adalah analisis regresi berganda 
menggunakan program SPSS. Hasil dari penelitian adalah adanya faktor-faktor motivasi seperti gaji, lingkungan kerja, hubungan interpersonal, dan keamanan kerja berpengaruh positif terhadap kinerja karyawan. Penelitian terbaru menunjukkan bahwa motivasi prososial dapat memprediksikan tingkat kinerja yang lebih tinggi di dalam pekerjaan (Perry \& Hondeghem, 2008), pemadaman kebakaran dan penggalangan dana (Grant, 2008; Rioux \& Penner, 2001), perawatan (Riggio \& Taylor, 2000), pekerjaan rumah sakit dan pendidikan (Ilies, Scott, \& Judge, 2006), dan engineering (Kamdar \& Van Dyne, 2007 ; Moon, Kamdar, Mayer, \& Takeuchi (2008). Sedangkan menurut Joko Purnomo (2008) dalam penelitiannya mengenai kepemimpinan, motivasi kerja, dan lingkungan kerja, terhadap kinerja karyawan menunjukkan hasil yang signifikan. Dimana variabel motivasi kerja dan lingkungan yang mempunyai pengaruh yang signifikan terhadap kinerja karyawan.

\section{Kerangka Pemikiran}

Berdasarkan tinjauan landasan teori dan penelitian terdahulu, maka dapat disusun suatu kerangka pemikiran dalam penelitan ini, seperti yang disajikan dalam gambar berikut ini:

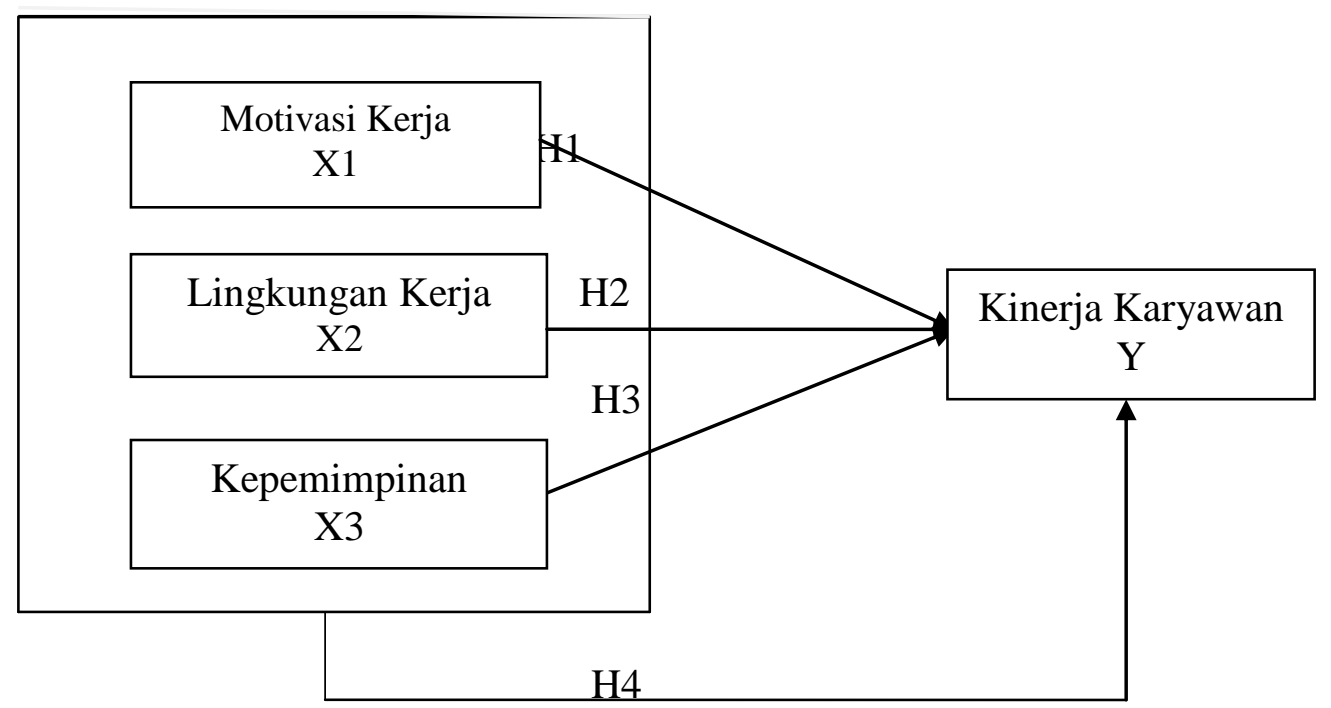

H1: Motivasi kerja berpengaruh positif terhadap kinerja karyawan

H2 :Lingkungan kerja berpengaruh positif terhadap kinerja karyawan.

H3 : Kepemimpinan berpengaruh positif dan signifikan terhadap kinerja karyawan

ISSN: $2337778 \mathrm{X}$ 
H4: Motivasi kerja, lingkungan kerja, dan kepemimpinan berpengaruh positif terhadap kinerja karyawan.

\section{METODE PENELITIAN}

Penelitian dilakukan di Kantor CV Marthani Surakarta. Populasi penelitian ini adalah seluruh karyawan dengan jumlah 35 orang karyawan. Sedangkan teknik pengambilan sampelnya menggunkan teknik sensus. Sampelnya di ambil adalah keseluruhan dari populasi yang ada sehingga dari 35 populasi memiliki kesempatan yang sama untuk menjawab setiap pertanyaan yang sudah diberikan lewat kuesioner yang disebarkan. Pengujian hipotesis dilakukan dengan persamaan regresi berganda, dengan rumus:

$$
\begin{aligned}
& \mathrm{Y}=\mathrm{a}+\mathrm{b} 1 \mathrm{X} 1+\mathrm{b} 2 \mathrm{X} 2+\mathrm{b} 3 \mathrm{X} 3 \\
& \text { Keterangan }: \\
& \mathrm{Y}=\text { Kinerja Karyawan } \\
& \mathrm{a} \quad=\text { konstanta } \\
& \mathrm{X} 1=\text { Motivasi kerja } \\
& \mathrm{X} 2=\text { Lingkungan Kerja } \\
& \mathrm{X} 3=\text { Kepemimpinan }
\end{aligned}
$$

\section{Uji T (regresi parsial)}

a. Menentukan formulasi hipotesis

Ho:b1 = 0 artinya, tidak ada pengaruh dari masing-masing variabel bebas $(\mathrm{x})$ terhadap variabel terikat $(y)$.

Ha:b1 $\neq 0$ artinya, ada pengaruh dari masing-masing variabel bebas $(\mathrm{x})$ terhadap variabel terikat $(y)$.

b. Menentukan derajat kepercayaan $95 \%(\alpha=0.05)$.

c. Menentukan signifikansi

Nilai signifikansi $(P$ value $) \leq 0,05$, maka Ho ditolak dan Ha diterima.

Nilai signifikansi $(P$ value $)>0,05$, maka Ho diterima dan Ha ditolak.

\section{Uji F (regresi simultan)}

a. Menentukan formulasi hipotesis

$$
\begin{gathered}
\text { Ho:b1 }=0 \text { artinya, semua variabel bebas }(\mathrm{x}) \text { secara simultan tidak } \\
\text { mempengaruhi variabel terikat }(\mathrm{y})
\end{gathered}
$$


Ha:b1 $\neq 0$ artinya, semua varibael bebas $(\mathrm{x})$ secara simultan mempengaruhi variabel terikat (y).

b. Menentukan derajat kepercayaan $95 \%(\alpha=0,05)$.

c. Menentukan signifikansi

Nilai signifikansi $(P$ value $) \leq 0,05$, maka Ho ditolak dan Ha diterima.

Nilai signifikansi $(p$ value $)>0,05$, maka Ho diterima dan Ha ditolak.

\section{ANALISIS DAN PEMBAHASAN}

Dari hasil penelitian menggunakan uji hipotesis menunjukkan sebagai berikut:

\section{Coefficients $^{\mathrm{a}}$}

\begin{tabular}{|c|c|c|c|c|c|c|c|}
\hline \multirow[t]{2}{*}{ Model } & \multicolumn{2}{|c|}{$\begin{array}{l}\text { Unstandardized } \\
\text { Coefficients }\end{array}$} & \multirow{2}{*}{$\begin{array}{c}\begin{array}{l}\text { Standardized } \\
\text { Coefficients }\end{array} \\
\text { Beta }\end{array}$} & \multirow[t]{2}{*}{$\mathrm{t}$} & \multirow[t]{2}{*}{ Sig. } & \multicolumn{2}{|c|}{$\begin{array}{c}\text { Collinearity } \\
\text { Statistics }\end{array}$} \\
\hline & B & $\begin{array}{l}\text { Std. } \\
\text { Error }\end{array}$ & & & & $\begin{array}{c}\text { Toleranc } \\
\text { e }\end{array}$ & VIF \\
\hline (Constant) & 2,463 & 3,170 & & ,777 & ,443 & & \\
\hline MotivasiKerja & ,560 & , 107 & ,587 & 5,213 &, 000 & ,825 & 1,213 \\
\hline $\begin{array}{l}\text { LingkunganKer } \\
\text { ja }\end{array}$ & , 187 & ,077 & ,259 & 2,428 & ,021 & ,916 & 1,091 \\
\hline Kepemimpinan & ,244 & ,101 & ,262 & 2,421 &, 022 & ,895 & 1,117 \\
\hline
\end{tabular}

a. Dependent Variable: KinerjaKaryawan

1. Motivasi kerja berpengaruh positif terhadap kinerja karyawan.

Dari hasil penelitian ini menunjukkan adanya Motivasi Kerja berpengaruh positif dan signifikan terhadap Kinerja Karyawan Di CV Marthani. Hasil ini memiliki kesamaan dengan penelitian yang dilakukan oleh Emilia Rosyana Putri (2001) dan Joko Purnomo (2008) dengan hasil motivasi kerja berpengaruh positif terhadap kinerja karyawan. Dibuktikan dari hasil uji t diperoleh Dari perhitungan tersebut diperoleh hasil dari thitung 
$=5,213>\mathrm{t}_{\text {tabel }}=2,040$, maka Ho ditolak sehingga ada pengaruh yang signifikan Motivasi Kerja terhadap Kinerja Karyawan.

2. Lingkungan kerja berpengaruh positif terhadap kinerja karyawan.

Dari hasil penelitian ini menunjukkan adanya Lingkungan Kerja berpengaruh positif dan signifikan terhadap Kinerja Karyawan CV Marthani. Hasil ini menunjukkan adanya kesamaan yang dilakukan oleh Penelitian yang dilakukan oleh Emilia Rosyana Putri (2001) dan Joko Purnomo (2008) dengan hasil lingkungan kerja berpengaruh positif terhadap kinerja karyawan. Dari perhitungan tersebut diperoleh hasil dari $t_{\text {hitung }}=2,428>t_{\text {tabel }}=2,040$, maka Ho ditolak sehingga ada pengaruh yang signifikan Lingkungan Kerja terhadap Kinerja Karyawan.

3. Kepemimpinan berpengaruh positif dan signifikan terhadap kinerja karyawan.

Dari hasil penelitian ini menunjukkan adanya Kepemimpinan berpengaruh positif dan signifikan terhadap Kinerja Karyawan Di CV Marthani. Hasil ini menunjukkan adanya kesamaan yang dilakukan oleh Penelitian yang dilakukan oleh Eka Idham Iip K Lewa dan Subowo (2005) dan Joko Purnomo (2008), dengan hasil kepemimpinan berpengaruh positif terhadap kinerja karyawan. Dari perhitungan tersebut diperoleh hasil dari $t_{\text {hitung }}=2,421>t_{\text {tabel }}=2,040$, maka Ho ditolak sehingga ada pengaruh yang signifikan Kepemimpinan terhadap Kinerja Karyawan.

4. Motivasi kerja, lingkungan kerja, dan kepemimpinan berpengaruh positif terhadap kinerja karyawan.

Dari hasil penelitian ini menunjukkan adanya Kepemimpinan berpengaruh positif dan signifikan terhadap Kinerja Karyawan Di CV Marthani. Hasil ini menunjukkan adanya kesamaan yang dilakukan oleh Penelitian yang dilakukan oleh Joko Purnomo (2008) bahwa motivasi kerja lingkungan kerja, dan kepemimpinan berpengaruh positif terhadap kinerja karyawan. Dibuktikan dari hasil uji $\mathrm{F}$ diperoleh hasil perhitungan yang diperoleh nilai $F_{\text {hitung }}$ sebesar 21,567, angka tersebut berarti $F_{\text {hitung }}$ lebih besar daripada $F_{\text {tabel }}$ sehingga keputusannya menolak Ho. Ketiga 
variabel independen signifikan mempengaruhi kepuasan Kinerja Karyawan Di CV Marthani secara simultan.

\section{Kesimpulan dan Saran}

1. Berdasarkan hasil perhitungan diperoleh hasil persamaan regresi sebagai berikut : $Y=2,463+0,560 X_{1}+0,187 X_{2}+0,244 X_{3}+e$.

2. Berdasarkan uji $\mathrm{t}$ diperoleh hasil perhitungan nilai $t_{\text {hitung }}$ dari variabel Motivasi Kerja sebesar 5,213, Lingkungan Kerja sebesar 2,428 dan Kepemimpinan sebesar 2,421 lebih besar daripada nilai $t_{\text {tabel }}=2,040$, berati Ho ditolak sehingga ada pengaruh Motivasi Kerja, Lingkungan Kerja dan Kepemimpinan yang signifikan terhadap Kinerja Karyawan secara individu. Dari hasil penilitian ini menunjukan bahwa hipotesis Motivasi Kerja berpengaruh positif dan signifikan terhadap Kinerja Karyawan Di CV Marthani, Lingkungan Kerja berpengaruh positif dan signifikan terhadap Kinerja Karyawan Di CV Marthani, Kepemimpinan berpengaruh positif dan signifikan terhadap Kinerja Karyawan Di CV Marthani terbukti kebenarannya.

3. Berdasarkan uji $\mathrm{F}$ diperoleh hasil perhitungan nilai $\mathrm{F}_{\text {hitung }}$ sebesar 21,567, angka tersebut berarti $F_{\text {hitung }}$ lebih besar daripada $F_{\text {tabel }}$ sehingga keputusannya menolak Ho. Dengan demikian secara simultan variabel Motivasi Kerja, Lingkungan Kerja, dan Kepemimpinan signifikan mempengaruhi Kinerja Karyawan CV Marthani.

4. Dari hasil perhitungan diperoleh nilai koefisien determinasi (Adjusted $\mathrm{R}^{2}$ ) sebesar 0,645, hal ini berarti bahwa variabel independen dalam model (Motivasi Kerja, Lingkungan Kerja, Dan Kepemimpinan) menjelaskan variasi Kinerja Karyawan Di CV Marthani sebesar 64,5\% dan 35,5\% dijelaskan oleh faktor atau variabel lain di luar model.

\section{Saran}

1. Perusahaan dalam usaha meningkatkan kinerja karyawan dengan memperhatikan faktor motivasi kerja misalnya meningkatkan insentif, pemberian promosi jabatan. 
2. Perusahaan dalam usaha meningkatkan kinerja karyawan dengan memperhatikan faktor lingkungan misalnya menciptakan hubungan yang harmonis antar karywan dan pimpinan serta memberikan fasilitas ruangan yang nyaman dan tenang. Yang harus di perhatikan di CV Marthani antara lain yaitu sirkulasi udara yang lebih banyak serta layout / tata letak peralatan pabrik yang teratur dan tempat parkir yang lebih luas demi kenyamanan dan keamanan para karyawan saat bekerja.

3. Perusahaan dalam usaha meningkatkan kinerja karyawan dengan memperhatikan faktor kepemimpinan misalnya memberikan kesempatan kepada karyawan dalam pengambilan keputusan dan diharapkan pemimpin mempunyai sifat demokratif terhadap karyawan.

4. Dengan hasil yang telah diteliti semoga perusahaan lebih memperhatikan berbagai aspek antara lain Motivasi kerja, Lingkungan kerja, dan kepemimpinan sehingga karyawan merasa aman dan nyaman saat melakukan aktivitas di dalam perusahaan. 


\section{DAFTAR PUSTAKA}

Alex S. Nitisemito, 2002. Manajemen Personalia. Ghalatia Indonesia, Jakarta.

Alfred Lateiner, 1985. Tehnik Memimpin Pegawai dan Pekerja. Terjemahan Imam Soejono. Jakarta: Aksara Baru.

Arep, 2003. Manajemen Sumber Daya Manusia. Penerbit Universitas TrisSakti Jakarta.

Baihaqi, M.F. (2010). Pengaruh Gaya Kepemimpinan Terhadap Kepuasan Kerja dan Kinerja Dengan Komitmen Organisasi Sebagai Variabel Intervening. Skripsi. Universitas Diponogoro, Semarang.

Blau and Scott, 1962. Formal Organization San Fransisco. (dalam Journal of Applied Psychology 2009 Vol. 94 No. 4.927 - 944).

Cahyono dan suharto, 2005, Pengaruh Budaya Organisasi, Kepemimpinan dan Motivasi Kerja

Dessler, 1992. Manajemen Personalia. Erlangga, Jakarta.

Eka Idham Lip K Lewa dan Subowo, 2005. "Pengaruh Kepemimpinan,

Lingkungan Kerja Fisik dan Kompensasi Terhadap Kinerja Karyawan

Di PT. Pertamina Persero (Daerah Operasi Hulu) Jawa Bagian Barat,

Cirebon". Jurnal Fakultas Ekonomi Universitas Islam Indonesia.

Emilia Rosyana Putri, 2001. Pengaruh Lingkungan Kerja Terhadap Kinerja Karyawan Bagian Produksi PT. Glory Industrial Semarang II. Semarang. Universitas Negeri Semarang.

Ferdinand, 2006. Metode Penelitian. Badan Penelitian Universitas Diponegoro Semarang.

Fuad Mas'ud, 2004, Survai Diagnosis Organisasional, Konsep dan Aplikasi, Badan Penerbit Universitas Diponegoro.

Ghozali (2001), Reliabilitas dan Validitas, Pustaka Pelajar, Yogyakarta

Gibson, 1996. Organisasi Perilaku Struktur. Binarupa Aksara, Jakarta.

Grant, 2008. Does Intrinsic Motivation Fuel the prosocial fine. (dalam Journal of Applied Psychology 93, 48-68).

Guritno dan Waridin, 2005. Pengaruh Persepsi Karyawan Mengenai Perilaku Kepemimpinan Kepuasan Kerja Dan Motivasi Terhadap Kinerja. JRBI.Vol 1.No 1. Hal: 63-74.Handoko, 1999. Manajemen. BPFE Yogyakarta

Handoko, 2000. Manajemen Personalia dan Sumber Daya Manusia. Badan Penelitian Fakultas Ekonomi Universitas Gajah Mada, Yogyakarta. 
Handoko, 2001. Manajemen Personalia dan Sumber Daya Manusia. Badan Penelitian Fakultas Ekonomi Universitas Gajah Mada, Yogyakarta.

Haryoto, 2002. Kinerja Organisasi Tersedia Online:http://lawu96.Multiply. com/journal/item/8 [26 April 2009].

Hidayat, 2006. Kamus Hubungan Industrial \& Manajemen Sumber Daya Manusia. Jakarta : Pustaka Jaya.

Ilies., Scott., and Judge., 2006. (Dalam Journal of Applied Psychology 93, 48$58)$.

Joko Purnomo, 2008. Pengaruh kepemimpinan motivasi dan Lingkungan kerja terhadap kinerja pegawai Negri sipil pada Dinas perkebunan Kabupaten Jepara.

Kamdar and Van Dyne, 2007. Moon Kamdar, Moyer and Takechi, 2008. ( dalam Journal of Applied Psychology 2009, Vol 94, No. 4, 927 - 944).

Katz dan Kahn, 1966. The Social Psychology of Organizations.

Komarudin, 2002. Manajemen Sumber Daya Manusia. Jakarta Salemba Empat.

Kusmawati, 2008. Diversifikasi, Kepemilikan Manajerial, Dan Kinerja Perusahaan. Jurnal Keuangan dan Bisnis. Vol.6 No.1 Hal. 12-23.

Manulang, 1982. Dasar - Dasar Manajemen. Ghalia Indonesia, Jakarta.

Masrukhin dan Waridin, 2006. Pengaruh Motivasi Kerja, Kepuasan Kerja, Budaya Organisasi Dan KepmimpinanTerhadap Kinerja Pegawai. EKOBIS. Vol 7. No 2. Hal:197-209.

Mathis, 2006. Manajemen Sumber Daya Manusia. Salemba Empat, Jakarta.

Moon., Kamdar., Mayer., \& Takeuchi., (2008). Me or We? The role of personality and justice as other-centered antecedents to taking charge within organizations. Journal of Applied Psychology, 93, 84-94.

Motowidlo, 2003. (dalam Journal of Applied Psychology, 93, 48 - 58).

Perry and Hondeghem. 200 ( dalam Journal of Applied Psychology 93, 48 - 58 ).

Riggio and Taylor, 2000. (dalam Jounal of Applied Psychology 93, 48-58).

Rioux \& Penner, 2001. The Causes Of Organizational Citizenship Behavior. A Motivational Analysis. Journal Of Applied Psychology. Vol 86, pp 372378. 
Robert Carison. Management Control System. New York: McGraw-Hill Education (Asia).

Sarwoto, 1991. Dasar-Dasar Organisasi dan Management Jakarta. Ghalia Indonesia.

Scott and Pandey, 2005. (dalam Journal of Applied Psychology 2009. Vol 94 No. 4927 - 944).

Sedarmayanti, 2001. Manajemen Perkantoran (dalam Jurnal Basuki dan Indah Susilowati). Mandar Maju, Bandung.

Simamora, 2004. Manajemen Sumber Daya Manusia. YKPN, Yogyakarta.

Sugiyono F, 1999. Statistika Untuk Penelitian Binarupa Aksara, Jakarta. Renstra Dinas Perindustrian dan Perdagangan Kota Semarang Tahun 2005.

Sugiyono, (2004). Metode Penelitian Bisnis, Cetakan keenam, Alvabeta, CV Bandung.

Suranta. 2002. Prinsip-prinsip Akuntansi untuk Kelas 2 SMU. Jakarta.Yudhistira Cahyono dan Suharto. 2005, Pengaruh Budaya Organisasi, Kepemimpinan dan Motivasi Kerja Terhadap Kinerja Sumber Daya Manusia, di sekretariat DPRD Propinsi Jawa Tengah, JRBI. Vol. 1, No.1, Januari 2005: 13-30.

Supranto, 2003. Metode Riset.Rineka, Jakarta.

Triantoro Safaria. 2004. "Kepemimpinan”. Cetakan Pertama, Graha Ilmu. Yogyakarta.

Umar, 2000. Riset Pemasaran dan Perilaku.PT. Gramedia Pustaka Utama dan Jakarta Business Research Centre, Jakarta.

Waldman, 2003. "The Contribution of Total Quality Management to a Theory of Work Performance", Academy of Management Review, Vol 19 No.3, pp 210.

Waridin 2005. Menciptakan Lingkungan Pembelajaran yang Kondusif. Upi Bandung.

Warella dan Hidayat, 2006. Descriptive Analysis of Labor Union Policy for Solving the Strike and Achieving Hygienic Management in Serikat Pekerja Seluruh Indonesia. Medan : Fakultas Ekonomi-Universitas Negeri Medan.

Weick, 1984.'Theory constructioas discipline dimagination' of Management Review 14/4. 